HISTORIA: Jurnal Pendidik dan Peneliti Sejarah, 4(1), 1-8. DOI: https://doi.org/10.17509/historia.v4i1.23984.

Available online at HISTORIA; Jurnal Pendidik dan Peneliti Sejarah
Journal homepage: https://ejournal.upi.edu/index.php/historia

\title{
THE ROLE OF CULTURAL RESERVATION CENTER (BPCB) JAMBI IN PRESERVING HISTORY SITE: SITUS BUKIT SIGUNTANG
}

\author{
Andi, Rudy Gunawan, Nadia Utami, Ainul Rizki, Hana Fatimah Azzahra \\ Program Studi Pendidikan Sejarah, FKIP Uhamka \\ Andi@uhamka.ac.id
}

To cite this article: Andi Dkk. (2021). The role of cultural reservation center (BPCB) Jambi in preserving history site: Situs bukit siguntang. HISTORIA: Jurnal Pendidik dan Peneliti Sejarah, 4(1), 1-8. https://doi.org/10.17509/historia.v4i1.23984

Naskah diterima : 9 April 2020, Naskah direvisi : 20 November 2020, Naskah disetujui : 29 November 2020

\begin{abstract}
Palembang is the oldest city in Indonesia, a historic city, and a city that is respected with the greatness of the glory of the Srivijaya kingdom. Various events have become important historical traces for the local and general public, one of the historical traces is historical sites. The many historic sites in Indonesia make the central government make laws about cultural heritage that must be preserved. One of the famous sites in Palembang is the Siguntang Hill Site. The management of the Bukit Siguntang Site is entered into the regional government and overseen by the BPCB. The purpose of this study was to determine the role of the BPCB Jambi on the Bukit Siguntang Site and the local government that included the community in the preservation of the Siguntang Hill Site. Data collected through a qualitative approach by exploring and interviewing participants accompanied by a review of various literature. The results of this study are that Jambi BPCB has a sufficient role especially in zoning the Bukit Siguntang Site area which is divided into three zones, namely: the core zone, the buffer zone, and the development zone. The regional government develops and utilizes the Siguntang Hill Site by building various supporting facilities to become historical attractions. The conclusion is that the BPCB Jambi has a role in preserving the Bukit Siguntang Site through supervision and monitoring as well as activities that involve collaboration with the local regional government.
\end{abstract}

Keywords: BPCB; historical site; material culture; Siguntang Hill Site. 


\section{Andi, Rudy Gunawan, Nadia Utami, Ainul Rizki, Hana Fatimah Azzahra \\ The Role of Cultural Reservation Center (BPCB) Jambi in Preserving History Site: Situs Bukit Siguntang}

\section{INTRODUCTION}

Palembang is a historical and highly respected city with the greatness and glory of the Srivijaya kingdom (Lussetyowati, 2015). Sriwijaya Kingdom is the first national kingdom in the archipelago, supported by the Kedukan Bukit inscription which says that Palembang has been a city since June 16, 682 AD So, it can be said that Palembang is the oldest city in Indonesia. Various events that occurred in the past left important historical marks for local people or Indonesian society in general. These historical traces include places or historical sites and relics of historical objects. Historical sites are areas where historical objects or values are found. A place can be said to have historical value, among others, if there are historical relics in that place and is a place of birth, death, important figures, temples, historical tombs, historic mosques (Wibowo, 2016).

Material culture is an aspect of culture that is material in nature, however, behind it, there is a certain meaning (Piliang \& Adlin, 2003). Material culture as part of culture becomes a means of creating meaning and order in society (Tanudirdjo, 1997). Thus, material culture is not a fossilized behavior or a passive result of human action, but there is always an active reciprocal between human ideas and actions and "material culture". History education requires scientific archaeological studies that are scientific in nature to help history reconstruct the past and new meanings to get grades that students can take (Carr, 1985; Wineburg, 2001).

However, it must also be understood that historical education is not only a vehicle for the development of intellectual abilities and the pride of the past but also a vehicle to improve the ongoing socio-cultural-political, economic, social, and cultural life (Hasan, 1999). Thus, learning history requires contextual material as well. Elaine B Jhonson (2007: 20) explains that in contextual teaching and learning, students can absorb lessons if they capture meaning in the academic material they receive and they can relate it to the information they already have. This learning system needs to link the subject matter with new, contextual meanings of "material culture". Postmodern archaeological studies can contribute in the form of contextual and contemporary values that can strengthen national identity (Tanudirdjo, 1997).

For example, what is the meaning of the various historical monuments that students can see today? Alan S. Marcus and Thomas H. Levine (2010) entitled "Remember the Alamo? Learning History with Monuments and Memorials "shows that the Alamo monument in Washington D.C. can be used as a source of learning history to develop historical thinking skills. Monuments or monuments designed as memorial sites function as historical symbols so that they can be maintained in addition to forming an identity from generation to generation as well as maintaining national identity (Barton and Mccully, 2005: 89).

Historical sites can be interpreted that a site is an infinite area of land or place that has historical value and is 50 years old, while history is a true story proven by witness testimony and heritage sites. Historical sites are also state assets that should be protected and saved. by the government and society because in addition to having educational value, historical sites can also be used as cultural tourism (Purnamasari \& Wasino, 2011). Historical sites are related to local history, because they explain various important events that took place in the area. Historical and historical sites usually appear in certain places that have their own stories in the past (Boudiaf, 2019). The study of local history in Indonesia is still not much written due to limited sources, however historical sites can be used as primary data in exploring various historical facts.

Local historical sites have their own charm, usually tourists want to see uniqueness that does not exist in the area of origin or has never been found. For tourists, historical places are a unique attraction, at least this can motivate someone to take a historical tour (Prompayuk \& Chairattananon, 2016). The existence of historical sites is also very prone to criminal acts, for example being stolen or for sale by local residents to collectors of ancient relics. Therefore, researchers do not want future generations to be separated from their historical roots because of the destruction and destruction of historical sites. It is time for the government to be assisted by the community to trace major or minor historical sites in the form of historical writing (Wibowo, 2016). In the process of restoration, the structure of the building is strengthened by using materials that are similar to the original; modern methods are also used if not destroying the monument (Gnezdilov et al., 2019)

The large number of historical sites scattered throughout Indonesia has made the government pass a law that specifically regulates cultural heritage that must be preserved. The legal basis that regulates the management of cultural heritage in Indonesia is Law of the Republic of Indonesia Number 11 of 2010 concerning Cultural Heritage. "Cultural Heritage, is a material cultural heritage in the form of cultural heritage objects, cultural heritage buildings, cultural heritage structures, cultural heritage sites, and cultural heritage areas on land and / or in water that need to be preserved because its existence is important for history, science. , education, religion, and / or culture through a process of determination ". This law is an improvement over the previous law (Dhani et al., 2017).

The name Bukit Siguntang is actually called "Seguntang" because the community may slip up the speech, which is simpler or easier to call it, eventually the pronunciation changes slightly. Siguntang Hill has been found for a long time and has been known since the 80s. Siguntang Hill is one of the most important historical and cultural sites during the Srivijaya kingdom in Palembang. Geographically, the Siguntang Hill Site is located at an altitude of 26 meters above sea level and is the highest landscape in Palembang City (Nadaek, 2016). Siguntang Hill is astronomically located at the coordinate point S 2 $59^{\circ} 34.3^{\prime} \mathrm{E} 104^{\circ} 45^{\prime} 08.1$. The Siguntang Hill site is located on Jalan Sultan Mansyur. Administratively, the Siguntang Hill Site is an area of Bukit Lama Village, West Llir I District, Palembang City. The area of Bukit Siguntang is 12.8 hectares (Akbar \& Sosilawati, 2019). 
HISTORIA: Jurnal Pendidik dan Peneliti Sejarah, 4(1), 1-8. DOI: https://doi.org/10.17509/historia.v4i1.23984.

In 1920 and 1928, several fragments of statues were found at the foot of Siguntang Hill. After putting these fragments together, it turns out that the whole statue has a height of 277 $\mathrm{cm}$, a shoulder width of $100 \mathrm{~cm}$, and a thickness of $48 \mathrm{~cm}$, made of granite, there is a unisha and urna on the forehead between the eyes, wearing a folded and transparent robe. This statue is named the Siguntang Buddha Statue, and currently the statue is kept in the Archaeological Park of the Sriwijaya Kingdom (TPKS). Based on the findings of various artifacts since the early 20th century, archaeologists identified Bukit Siguntang as one of the religious sites, especially Buddhism. The Siguntang Hill site during the Sriwijaya era played an important role as a place of worship and pilgrimage for Buddhists. Bukit Siguntang in the Islamic era is considered the origin of the Malay kings in the archipelago. Another role is as a place for people to swear in case of disputes between residents (Nadaek, 2016).

Siguntang Hill becomes a place of pilgrimage tourism which is carried out by individuals or groups by visiting the graves of saints or famous people and exalted leaders. The goal is to get blessings, blessings, happiness and peace. This is because Siguntang Hill is sacred by some groups of people who believe that there are graves of the descendants of Sriwijaya kings, including Radja Sigentar Alam, Putri Kembang Dadar, Panglima Bagus Kuning, Panglima Bagus Karang, Putri Rambut Selako, Pangeran Radja Batu Api, Panglima Tuan Djundjungan. .

The management of the Bukit Siguntang Site is carried out by the local government and supervised and monitored by $\mathrm{BPCB}$. The Cultural Heritage Conservation Center (BPCB) is the technical implementation unit of the Ministry of Education and Culture in the field of cultural heritage preservation which is under and responsible to the Director General of Culture. $\mathrm{BPCB}$ is tasked with implementing protection, development and utilization of cultural heritage and those suspected of being cultural heritage in its working area. The function of BPCB is to carry out rescue and security, zoning, maintenance, development, utilization, documentation and publication, implementation of partnerships in the field of preservation of cultural heritage and suspected cultural heritage (Culture, 2016).

The South Sumatra region is included in the scope of the Jambi BPCB. Therefore, the person responsible for handling historical and cultural sites in Palembang is the Jambi BPCB.The Jambi Cultural Heritage Preservation Center was originally named as the Jambi Heritage and Archaeological Heritage Reserve which was established based on the Decree of the Directorate General of Culture, Ministry of Education and Culture, number 0767/0/1989 dated December 7, 1989. Then, according to the Decree of the Minister of Culture and Tourism, number KM. 51 / OT.001 / MKP / 2003 concerning the Organization and Administration of the Archaeological Heritage Conservation Center (BP3) Jambi is one of the technical implementing units of the Ministry of Culture and Tourism, under the Director of Purbakala Heritage, Directorate General of History and Antiquities.
In accordance with the Presidential Regulation of the Republic of Indonesia Number 92 of 2011 concerning Second Amendment to Presidential Regulation Number 24 of 2010 concerning the Position, Duties and Functions of State Ministries as well as the Organizational Structure, Duties and Functions of Echelon I of State Ministries, DirectorateDirectorate of Culture at the Ministry of Culture and Tourism is under one Directorate General at the Ministry of Education and Culture, namely the Directorate General of Culture. Since the enactment of the Regulation of the Minister of Education and Culture number 52 of 2012 dated 20 July 2012 concerning the Organization and Work Procedure of the Cultural Heritage Conservation Center, the Jambi Archaeological Heritage Preservation Center has been transformed into the Jambi Cultural Heritage Conservation Center with a working area of Jambi Province, South Sumatra,

At the beginning of its establishment, the Jambi Cultural Heritage Conservation Center occupied a room at Hotel Pinang Jalan Dr. Sutomo N0 9 Jambi City from 22 June-3 July 1990. On 3 July-3 October 1990 moved from Pinang Hotel to Jambi Province State Museum (Siginjai Jambi Museum). On October 3, 1990, the Jambi Cultural Heritage Conservation Center occupied a house on Jalan Empu Sendok, Jambi City. It was only in 1992 that the Jambi Cultural Heritage Preservation Center had an office building on Jalan Samarinda, Kotabaru, Jambi City which is in use until now. Since its establishment until today, the Jambi Cultural Heritage Conservation Center is led by Drs. Junus Satrio Atmodjo (1990-1997), Drs. Gatot Ghautama, MA (1998-2002), Drs. I Made Suantra (2002-2005), Drs. Winston SD Mambo (2005-2016), Drs. Muhammad Ramli (2016-2018), Iskandar Mulia Siregar S.(Culture, 2016).

The vision of BPCB Jambi is the realization of optimal preservation and utilization of cultural heritage supported by professional Human Resources and community participation, then the mission of BPCB Jambi is as follows:

1. Increasing efforts to preserve and utilize cultural heritage in Jambi, South Sumatra, Bengkulu and Bangka-Belitung Provinces.

2. Improve the professionalism of human resources in the field of preservation and utilization of cultural heritage and sites.

3. Increase cooperation between agencies and across sectors.

4. Increase public awareness of the preservation of cultural heritage and sites.

5. Cooperating with the community in dealing with the preservation of cultural heritage objects.

There is great hope for the local government and the Jambi BPCB which covers the South Sumatra area, to continue to be able to maintain and preserve the Siguntang Hill Site. Because the site can be concrete evidence of historical events in the past, where there was a great triumph of the Srivijaya kingdom and became the center of Buddhist worship. After seeing the conditions and facts contained in the Bukit Siguntang site, that the authenticity of the site has been doubted and many changes have occurred. Based on this, the researcher wants to try to assess, What is the role of BPCB Jambi in the preservation 
of the Bukit Siguntang Site? Does BPCB Jambi involve the surrounding community in preserving the Bukit Siguntang Site? How is the collaboration between BPCB Jambi and the local government in preserving the Bukit Siguntang Site? How is the current state of the Siguntang Hill Site as evidence of historical heritage?

\section{METHOD}

This research uses descriptive exploratory method, namely by field studies and interviews with the community. Samples for interviews were representatives of local communities living in heritage areas. To find out this symptom, the researcher interviewed the participants by asking general questions. The information submitted by the participants is then collected. This information is usually in the form of text or words. The data obtained were then analyzed by researchers. The results of the analysis are in the form of a description or description (Raco, 2013). This research is a qualitative research because the nature of the data collected is qualitative, not quantitative, because it does not use measuring tools. Qualitative research is also called naturalistic research because the research field situation is natural or natural, as it is, without being manipulated, regulated by experiments or tests.

The data obtained in this study used primary data. Primary data is data in the form of verbal or spoken words, gestures or behaviors carried out by reliable research subjects (informants). Primary sources in this study are the results of audio interviews and direct observations used by researchers to clarify the role of the Jambi Cultural Heritage Conservation Center (BPCB) in preserving historical sites: the Siguntang Hill Site. Secondary sources are data that come from reading sources and various other sources, ranging from personal letters to official documents. Secondary data can be in the form of newsletters, surveys and so on (Rahmat, 2009).

\section{RESULTS AND DISCUSSION}

\section{The Role of BPCB Jambi in Conservation of the Bukit Siguntang Site}

Based on the Permen Mendikbud RI Number 52 of 2012 concerning the Organization and Work Procedures of BPCB, BPCB has the following duties and functions: BPCB has the task of carrying out protection, development, utilization and facilitation of the preservation of cultural heritage in its working area. The South Sumatra (Palembang) region is included in the scope of the Jambi BPCB. The Siguntang Hill site is a historical and cultural site, a relic of the past glories in the Palembang area of South Sumatra. Considering that this building is a relic of the past, it is necessary to preserve it. It is hoped that the existence of preservation measures can keep the Bukit Siguntang Site in existence and its authenticity is maintained as authentic evidence of historical events.
In the preservation of a historical and cultural site, a special body that is expert and responsible and formed by the government is required. In this case, the Cultural Heritage Conservation Agency (BPCB) has been established. BPCB has various duties and functions that they must perform as an effort to preserve historical and cultural heritage. The role of BPCB Jambi in preserving the Bukit Siguntang site is sufficient. In the nearest future, revitalization has been carried out in 2017-2018. In carrying out various activities including revitalization, delineation, research, excavation and others, many parties are involved, namely the Jambi BPCB, the South Sumatra Archaeological Center, the Culture and Tourism Office, and the local government. The initial action in the context of preserving and protecting the Siguntang Hill Site was carried out by the Archaeological Center of South Sumatra because the coverage is closer and the Siguntang Hill Site is a regional site. At that time, the South Sumatra Archaeological Center routinely conducted research and excavation in the Siguntang Hill area.

As time went on and an update was needed, the South Sumatra provincial government requested assistance from the Jambi BPCB to conduct a study related to the Bukit Siguntang site area. With the aim of helping development, including the construction of a gallery or exhibition space and the construction of other facilities. In carrying out development, it must be adjusted to the character of the site so that it does not appear to be contrasting, therefore in development, it must prioritize the natural character of a hill filled with green trees and all existing landscapes. After conducting a study, BPCB Jambi made zoning on the Bukit Siguntang Site which was carried out in 2018 and divided into three zoning, namely the core zone, the buffer zone and the development zone. A zoning study is needed because BPCB is indeed obliged to divide the space for future development and utilization. The zoning study is a concrete action from the Jambi BPCB in assisting the preservation, development and utilization of the Bukit Siguntang Site.

The core zone is the central zone of cultural heritage itself, so it can be said to be the main protector and place of various historical relics that reside in the area. The core zone cannot be tampered with or changed and it is related to all kinds of objects from the past. The core zone at the Siguntang Hill Site is the peak part because previously the hill was used as the main marker. If for cultural heritage in the form of a structure found on the hillside. The buffer zone acts as a protection for the core zone, which is a zone where physical activities are allowed, but it is not done permanently nor does it damage the core zone. In this zone must be done carefully and not arbitrarily in order to maintain the core zone.

The development zone is an area that is developing cultural heritage values. This zone is a zone where actualization can be carried out as a means of development and utilization. Not just any facility can be built, but must develop the potential of cultural heritage. And it is a zone where various economic activities are allowed, such as locations for selling, locations 
HISTORIA: Jurnal Pendidik dan Peneliti Sejarah, 4(1), 1-8. DOI: https://doi.org/10.17509/historia.v4i1.23984.

for souvenirs, parking lots, toilets and so on. In the current development zone, there is a gallery that is intended as a means of education for visitors and the public.

Supposedly this development zone was built outside and now the situation is being built in the site area. Because there is already a minimum area while this site must continue to be used, a development zone was built in the part that was already built by the local local government beforehand, so that it could be in harmony with one another. When doing zoning, you must look at the previous conditions, so you cannot be truly idealistic in determining the zone. The space arrangement is only to control the construction carried out on the site. Except in the core zone, it should not be disturbed or changed at all.

In addition to zoning, other actions carried out at the Siguntang Hill Site were demolition of several buildings that did not fit the context of Bukit Siguntang. For example, the demolition of the tower of view that is not in accordance with historical facts. Then the local government also made a roof to protect the existing tombs, and the construction of a pond at the top of Siguntang Hill. Actually, according to the Jambi $\mathrm{BPCB}$ regarding tombs and ponds, it is not in accordance with the context of the site, especially since previously as a place of worship for Hinduism / Buddhism, there was clearly no grave there. Even when this site was discovered there was only one tomb and now there are seven. And this place can be concluded that it has been sacred by the surrounding community and is famous for its tomb.

BPCB Jambi recognizes the Bukit Siguntang site as a Buddhist site that is still preserved until now because statues and structures and ceramics have been found as evidence of past heritage and also used as an Islamic burial site. If scientifically the grave is actually questionable, but because it has been trusted by the surrounding community, it is left alone. The tomb exists because the use of the place continued in the aftermath, namely the Islamic era. However, because it is already there and there is such a thing and has become an asset of the local government, it is left to destroy and when it is no longer an asset it must be destroyed and returned to its original position.

\section{Participation of the Local Community in the Conservation of the Bukit Siguntang Site}

Most of the Malay community in Sumatra and the Malay peninsula consider Bukit Siguntang sacred, because it is the place of origin of the ancestors of the Malay people. The Siguntang Hill site is also the location of Parameswara, the king of Palembang who sent down the kings of the Malay peninsula (Nadaek, 2016).

The Siguntang Hill site, which was known during the Sriwijaya kingdom and has relics from the kingdom, makes this hilly area in Palembang holds many historical values. From these historical values, the local government is obliged to preserve and utilize it, actions that must be taken are to make it a tourist attraction known as the Bukit Siguntang tourist attraction. cultural heritage and historical heritage are very valuable and often irreplaceable and must be preserved and preserved. Apart from being a vehicle for education, sites and cultural heritage objects can also be used for tourism, and it is important to protect them in the long term. Preservation of cultural heritage and traditions is important to be preserved as part of the history of a city.

In the tourism sector, language is an important aspect for its growth and development. In this world, there are various kinds of languages that we must learn, especially English because English is an international language that has been used all over the world as a means of communication between countries that have different languages, English has an important role for tourism development, especially in Palembang (Ujihanti et al., 2019).

As one of the tourist objects that has great potential for foreign tourists to visit, the Siguntang Hill Site has reasons to participate in English training for tourist attraction guides and local communities, thus equipping tour guides and local people to be able to speak English at any time. there are tourists visiting the Siguntang Hill Site. This training is one of the ways to fulfill the era of industrial revolution 4.0 which refers to meeting professionalism and competition is a requirement that must be met so that it becomes a reference in carrying out their duties.

Jambi BPCB involves the local community in preserving the Bukit Siguntang Site. Here BPCB Jambi appealed to the community that they were not allowed to make permanent buildings or carry out activities that could damage the sustainability of the Bukit Siguntang Site. The local community understands and obeys the recommendations and regulations given to maintain the harmony of the Siguntang Hill Site.

It is the responsibility of the local government to involve the community in conservation. However, it must also be remembered that those who are responsible for preserving cultural heritage are not only the BPCB or the local government but the community is also obliged to take part there for the sustainability of the site so that it is maintained. Local people are expected to be at the forefront of protecting their cultural and historical wealth as a nation's wealth that future generations are proud of. Existing cultural heritage buildings must be preserved in order to maintain the authenticity of the cultural heritage areas. The authenticity of the unique and charming cultural heritage buildings will add real value and attractiveness to tourism. The Bukit Siguntang site is not only a place for education in the history of Palembang, but also as a tourist attraction.

\section{Collaboration between BPCB Jambi and Local Government in Conservation of the Bukit Siguntang Site}

Jambi BPCB does not work alone in handling the Siguntang Hill Site. They coordinate and cooperate with related parties and local government to carry out various activities. During the 2018 zoning activities, a collaboration was held between the Jambi BPCB and the local government, and the 


\section{Andi, Rudy Gunawan, Nadia Utami, Ainul Rizki, Hana Fatimah Azzahra \\ The Role of Cultural Reservation Center (BPCB) Jambi in Preserving History Site: Situs Bukit Siguntang}

budget used was from the local government. Previously, it was still running independently and the local government emphasized the utilization side so that the Siguntang Hill Site could be used as a tourist attraction. Besides that, the local government must also be responsible for the protection and preservation of the Bukit Siguntang Site, not just utilization. Because not everything must be borne by the Jambi BPCB. Moreover, this site is regional in nature and BPCB has the duty to supervise and monitor.

\section{Condition of the Siguntang Hill Site}

Siguntang Hill used to be a village and when it was first discovered there was a burial complex there, then the grave was finally moved by the community and only one grave was left. Over time the tomb increased to seven and is believed by the surrounding community as a sacred tomb. Besides that, various relics of the Sriwijaya kingdom have been found in the form of statues, ceramics, and others. Even ceramic fragments are still embedded in the ground on the slopes of Bukit Siguntang. The condition of Bukit Siguntang has been damaged since the 90 s and many changes have occurred since the governor's position at that time. However, during the administration of Pak Alex Noerdin, he was very busy raising the issue of Siguntang Hill regarding its authenticity.

According to Mrs. Retno from the South Sumatra Tourism and Culture Forum, she said that the essence of Bukit Siguntang is now better and more complete than it used to be. The main problem that occurs is the existence of a fountain at the top of Siguntang Hill which reduces the essence there, considering that it is the highest plain in South Sumatra. And it should only be left in the form of a field like a hill in general. In the past, in every tomb, a pyramid-shaped roof was made, but since 2017 it has been changed to a more modern form and the use of this roof is useful as protection from hot and rainy weather.

In the view of archeology, there is a radius stipulation, where when the radius has passed, a new building can be made without losing the essence of the historical or cultural site, the most important thing is that the main building is maintained. So in fact, the Bukit Siguntang Site is not disturbed, but the spirit is now increasingly visible, although there are a few that are still inaccurate. In the past, a tower of view had been built there which was useful to see the entire region of South Sumatra, and this was not quite right, but in the end the tower was torn down to restore the existing essence.

Even the path in the form of stairs made to climb the hill was built during the governor's time before Mr. Alex and it is not quite right if it is related to the essence of Bukit Siguntang which is actually a natural hill. At the top of Siguntang Hill previously there were reliefs and markers of five religious figures in Indonesia. If we examine it, it turns out that it is not related, because during the Srivijaya kingdom, Buddhism was more prominent. This development occurred during the
New Order era and at that time there was very little access to criticizing the government. It can be said that Siguntang Hill has long been changed and its authenticity has been lost. However,

In the story, the ancient man descended on Siguntang Hill and gave birth to the kings of the Srivijaya kingdom. There are several tombs there who belong to the Srivijaya royal army, and Sriwijaya's records are not clear about this. According to archaeologists, if you want to find out about Siguntang Hill which is actually related to tombs, you have to dismantle the graves, but maybe there is nothing in them, let alone bodies. In doing so, instructions from related parties are required. When the 90 s began construction there, such as, made a roof over the tomb and so on.

During the reign of Mr. Alex Noerdin, he wanted to build a gallery on the Bukit Siguntang site which was not an easy thing, he invited several experts throughout Indonesia and that happened in the 90s. At that time was a time when all decisions were with the leader and it was inevitable. So it has violated the data since the 90s. For example, such as a ladder made to climb it, if you want to be questioned, it is clear that it violates the data because it used to be just land. For protection, therefore, a roof is given to each tomb. And the stairway was made to facilitate access when climbing the hill as a tourist attraction, because now the Siguntang Hill Site is used as a tourist spot. That is the main reason,

Basically, the existence of the tomb has nothing to do with the Siguntang Hill Site. Looking at the various relics and artifacts found in the form of ceramics, statues, and so on, it can be concluded that the Siguntang Hill Site was used as a place of worship during the Srivijaya kingdom in the 8th and 9th centuries AD. Because its use may continue, there are Islamic tombs. And the most important thing here is that the condition of the hill is maintained as physical evidence of historical heritage.

On Siguntang Hill there is a gallery that was built in 2017 on the initiation of the local government. The gallery construction aims to publish various things related to the Bukit Siguntang Site. Then it is also used as a medium for the community to find out the history and heritage that is there. The gallery construction is still inaccurate and a bit against the rules because it is constrained by a narrow area so that it cannot be built outside the hill location. If it is correlated with the field of archeology, in fact a gallery should not be built, but seeing the existing interests, the gallery was built while not disturbing the historical heritage and still prioritizing site protection.

\section{CONCLUSIONS}

Based on the results of this study, the following conclusions can be drawn: BPCB Jambi plays a significant role in preserving the Bukit Siguntang Site. Jambi BPCB collaborates with the 
HISTORIA: Jurnal Pendidik dan Peneliti Sejarah, 4(1), 1-8. DOI: https://doi.org/10.17509/historia.v4i1.23984.

local government to carry out various activities in terms of preserving the Siguntang Hill Site. Apart from the role of the Jambi BPCB and the local government which is responsible for preserving the cultural heritage of the Bukit Siguntang site, namely the participation of local people who are obliged to take part in the conservation of the Bukit Siguntang site for the sustainability of the site so that it is maintained. In addition, to maintain the cultural and historical wealth that it has as a nation's wealth that future generations are proud of, it is hoped that local communities will be able to become the front guard. Preservation, both the preservation of cultural heritage and nature reserves, is important. some of the main reasons for the protection of cultural heritage. First, cultural memory, preservation of cultural heritage, preserves the history of physical evidence and transfers the value of previous knowledge and skills. The second objective is a comfortable proximity, the preservation of cultural heritage can support the interaction between the environment, society and community activities. Furthermore, environmental diversity, as the identity or difference of local communities, preservation will maintain local artifacts and local craftsmen among the flow of urban development. The preservation of cultural heritage is also beneficial for the community in improving the economy of the community around the cultural heritage. preservation of cultural heritage preserves historical physical evidence and transfers the value of previous knowledge and skills. The second objective is a comfortable proximity, the preservation of cultural heritage can support the interaction between the environment, society and community activities. Furthermore, environmental diversity, as the identity or difference of local communities, preservation will maintain local artifacts and local craftsmen among the flow of urban development. The preservation of cultural heritage is also beneficial for the community in improving the economy of the community around the cultural heritage. preservation of cultural heritage preserves historical physical evidence and transfers the value of previous knowledge and skills. The second goal, comfortable proximity, preservation of cultural heritage can support the interaction between the environment, society and community activities. Furthermore, environmental diversity, as the identity or difference of local communities, preservation will maintain local artifacts and local craftsmen among the flow of urban development. The preservation of cultural heritage is also beneficial for the community in improving the economy of the community around the cultural heritage. preservation will preserve local artifacts and local craftsmen among the streams of urban development. The preservation of cultural heritage is also beneficial for the community in improving the economy of the community around the cultural heritage. preservation will preserve local artifacts and local craftsmen among the streams of urban development. The preservation of cultural heritage is also beneficial for the community in improving the economy of the community around the cultural heritage.

Based on the above conclusions, the suggestions that there are several recommendations for the development of the historical site of Bukit Siguntang, Palembang City, are:

1. The role of the Jambi Cultural Heritage Conservation Center (BPCB) is more active in helping preservation measures in maintaining the Bukit Siguntang Site to always exist and maintain its authenticity as authentic evidence of historical events.

2. Socialization to the public to be active in the development of the Bukit Siguntang site in Palembang City.

3. As the younger generation, at least we know about the local history that has occurred in our respective regions, and better understand the values contained therein.

\section{REFERENCES}

Akbar, T., \& Sosilawati, E. (2019). Menghitung cadangan karbon yang tersimpan di taman purbakala bukit siguntang palembang sumatera selatan. Sylva, 8(1), 2129.

Barton, C. K., \& Mccully, A. W. (2005). History, identity, and the school curriculum in Northern Ireland: an empirical study of secondary students' ideas and perspectives. Journal of Curriculum Studies, 37(1).

Boudiaf, B. (2019). Tourism and the heritage conservation of the historical areas. Abstract: October.

Dhani, O. U., Husaini, \& Abdullah, T. (2017). Peranan balai pelestarian cagar budaya (bpcb) aceh dalam pelestarian situs-situs bersejarah di kota banda aceh tahun 19902015. Jurnal Ilmiah Mahasiswa (JIM). Program Studi Pendidikan Sejarah, 2(1), 114-125.

Carr, E.H. (1985). What Is History?. Harmondsworth, Middlesex, England: Penguin Books, Ltd..

Gnezdilov, D. V., Kapnina, E. V., \& Martynyuk, E. S. (2019). The problem of preservation, restoration, and reconstruction of the world architectural heritage. IOP Conference Series: Materials Science and Engineering, 698(3). https://doi. org/10.1088/1757-899X/698/3/033022.

Hasan, S. H. (1999). Pendidikan sejarah untuk membangun manusia baru indonesia. Mimbar Pendidikan. 2.

Johnson, B. E. (2002). Contextual teaching and learning. California: Corwin Press, Inc.

Kebudayaan, K. P. (2016). Balai pelestarian cagar budaya. Kementerian Pendidikan Dan Kebudayaan. Direktorat Jenderal dan Kebudayaan.

Lussetyowati, T. (2015). Preservation and Conservation through Cultural Heritage Tourism. Case Study: Musi Riverside Palembang. Procedia - Social and Behavioral Sciences, 184(August 2014), 401-406. https://doi. org/10.1016/j.sbspro.2015.05.109. 
Marcus, A. S. \& Levine, T. H. (2010). Remember the alamo? learning history eith monumen dan memorials. Journal of Sosial Educatians, 74(1).

Nadaek, R. P. (2016). Bukit siguntang: peranannya dalam agama buddha pada masa kerajaan sriwijaya. Forum Arkeologi, 29(1), 11-20.

Piliang, Y. A., \& Adlin, A. (2003). Hipersemiotika: tafsir cultural studies atas matinya makna. Jakarta: Jalasutra.

Prompayuk, S., \& Chairattananon, P. (2016). Preservation of cultural heritage community: cases of thailand and developed countries. Procedia - Social and Behavioral Sciences, 234, 239-243. https://doi.org/10.1016/j. sbspro.2016.10.239

Purnamasari, I., \& Wasino, W. (2011). Pengembangan model pembelajaran sejarah berbasis situs sejarah lokal di SMA negeri kabupaten temanggung. Paramita - Historical Studies Journal, 21(2), 202-212.
Raco, J. R. (2013). Metode Penelitian Kualitatif Jenis, Karakteristik dan Keunggulannya. Jakarta: Grasindo.

Rahmat, P. S. (2009). Penelitian Kualitatif. Equilibrium, 5(9), $1-8$.

Ujihanti, M., Aryanti, N., Ramahania, R., Kardia, Y., \& Ridzka, A. (2019). Teknik pramuwisata dalam melayani wisatawan asing di objek wisata taman bukit seguntang palembang. Prosiding Applicable Innovation of Engineering and Science Research, 2019, 711-716.

Tanudirdjo, D.A. (1997). Arkeologi pasca modern untuk direnungkan: pertemuan ilmiah arkeologi VII Jilid 2. Jakarta: Pusat Penelitian Arkeologi Nasional 1997-1998.

Wineburg, S. (2006). Berpikir historis: Memetakan masa depan, mengajarkan masa lalu. Jakarta: Yayasan Obor Indonesia. 